\title{
KAJIAN KARAKTERISTIK PEDAGANG PENGUMPUL KENTANG KAITANNYA DENGAN STRATEGI DALAM UPAYA MENJAGA USAHA BERDAGANG DI DESA WONOKITRI, KECAMATAN TOSARI, KABUPATEN PASURUAN, JAWA TIMUR
}

\author{
ASSESSMENT OF CHARACTERISTICS OF MERCHANTS POTATOES \\ RELATION TO STRATEGY IN EFFORTS TO MAINTAIN BUSINESS \\ TRADE IN VILLAGE WONOKITRI, DISTRICT TOSARI, PASURUAN \\ REGENCY, EAST JAVA
}

\author{
Algar Khalili ${ }^{1 *}$, Mangku Purnomo ${ }^{2}$, Keppi Sukesi ${ }^{3}$ \\ Jurusan Sosial Ekonomi, Fakultas Pertanian,Universitas Brawijaya, Jl. Veteran 65145 Malang, \\ Indonesia
}

Received: 15th Desember 2015; Revised: 15th Desember 2015; Accepted: 18th Desember 2015

\begin{abstract}
ABSTRAK
Penelitian ini menggunakan pendekatan kualitatif melalui proses penggalian data dengan melihat strategi pedagang pengumpul dalam menjalankan usaha pemasaran kentang. Subyek dari penelitian ini adalah pedagang pengumpul kentang yang tersebar di Desa Wonokitri. Penentuan subyek penelitian dilakukan dengan teknik sensus, yaitu mengali informasi dari semua pedagang pengumpul yang ada di Desa Wonokitri berjumlah 14 orang informan. Teknik pengumpulan data adalah melalui wawancara secara mendalam (indepth interview), observasi partisipatif, dokumentasi, dan studi pustaka. Teknik analisis data sekunder menggunakan metode deskriptif sedangkan data primer dianalisis menggunakan model interaktif. Model interaktif terdiri dari tiga hal pokok, yaitu: reduksi data, penyajian data, dan penarikan kesimpulan. Hal tersebut saling berhubungan sehingga membentuk siklus interaktif. Berdasarkan penelitian disimpulkan sebagai berikut: karakteristik pedagang pengumpul berdasarkan skala distribusi dan pengalaman berdagang mempunyai pengaruh terhadap jangkauan pasar, pengambilan risiko, jaringan sosial dan kontrak bisnis. Berdasarkan faktor-faktor yang mempengaruhi, menghasilkan empat pola alternatif saluran yang diterapkan pedagang pengumpul. Pada setiap pola saluran alternatif tersebut diketahui bahwa strategi-strategi pedagang pengumpul, yaitu: berdasarkan pengalaman perdagangan dan skala distribusi diketahui bahwa pasar skala nasional lebih dominan dengan mengambil resiko yang tinggi untuk memaksimalkan keuntungan. Kemudian jaringan sosial yang sering dijalin oleh pedagang pengumpul adalah jaringan sosial melalui komunikasi langsung dengan melakukan kontrak bisnis yang mengikat melalui harga kentang.
\end{abstract}

Kata kunci: karakteristik pedagang pengumpul; strategi pedagang pengumpul; usaha berdagang kentang

\section{ABSTRACT}

This study used a qualitative approach through the process of extracting the data by looking at strategies traders in running the potato marketing efforts. The subject of this research is all the middlemen potato in the Village Wonokitri. The subjects were all intermediaries potatoes in the village Wonokitri total of 14 informants. The data collection technique is through in-depth interviews, participant observation, documentation, and literature. Secondary data analysis techniques using descriptive method, while the primary data were analyzed using an interactive model. Interactive model consists of three main points, namely: data reduction, data presentation, and conclusion. It is interconnected to form an interactive cycle. Based on research concluded as follows: characteristics middlemen based on distribution scale and experience have an influence on the market reach, taking risks, social networking and business contracts. Based on the factors that affect, produces four channels of alternative patterns applied middleman. Every alternate channel pattern is known that the strategies traders, namely: based on the experience of trade and scale of distribution is known that market more dominant national scale with high taking of risk in order to maximize profits. Then social networks are often carried by traders is a social network through direct communication with doing business contract binding through the price of potatoes.

Keywords: characteristics of middlemen; strategy of middlemen; trade of potato 


\section{Pendahuluan}

Produksi kentang di Jawa Timur terletak di Kabupaten Pasuruan, Magetan, Bondowoso, Lumajang, Probolinggo dan malang. Berdasarkan sebaran produksi kentang tersebut Kabupaten Pasuruan merupakan salah satu daerah potensial produksi kentang. Menurut Dirjen Pemberdayaan Masyarakat dan Desa (2014) wilayah penelitian yaitu di Desa Wonokitri, Kecamatan Tosari, Kabupaten Pasuruan luas lahan yang ditanam kentang tertinggi di wilayah Kecamatan Tosari yaitu $650 \mathrm{Ha}$, sedangkan produktivitasnya terus meningkat karena pembukaan lahan baru di Desa Wonokitri, Kecamatan Tosari, Kabupaten Pasuruan. Melihat potensi yang cukup tinggi, maka pemasaran kentang sangat potensial ke berbagai pasar yang ada di wilayah pasar lokal maupun pasar nasional.

Melihat besarnya potensi pemasaran kentang tersebut, muncul permasalahan, yaitu 1) budidaya kentang di wilayah penelitian yang produksinya terus menurun karena penurunan kualitas tanah, serta irigasi yang intensif ketika musim kemarau, 2) masalah distribusi kentang, yaitu kurangnya manajemen saluran pemasaran yang baik sehingga terkesan saluran pemasaran tersebut kurang sesuai dengan kuanitas kentang yang dikirim, 3) sifat kentang yang mudah rusak dan busuk, sehingga tidak dapat disimpan dalam jangka waktu relatif lama, 4) perubahan harga kentang dalam waktu yang singkat mengakibatkan besarnya potensi kerugian bagi pedagang, 5) kurangnya kemampuan pedagang pengumpul dalam menguasai pasar mengakibatkan sulitnya meningkatkan skala distribusi.

Berdasarkan permasalahan tersebut, maka dalam penelitian ini memiliki tujuan, yaitu: 1) Mengidentifikasi karakteristik pedagang pengumpul kentang di Desa Wonokitri, Kecamatan Tosari, Kabupaten Pasuruan, 2) Mengidentifikasi faktor-faktor yang mempengaruhi karakteristik pedagang pengumpul, 3) Menganalisis pola saluran pemasaran pedagang pengumpul, 4) Menganalisis strategi pedagang pengumpul dalam upaya menjaga usaha berdagang.

\section{Metode Penelitian}

Lokasi penelitian ini dipilih atas

\footnotetext{
${ }^{*}$ Penulis Korespondensi.

E-mail: algarkhalili@gmail.com
}

pertimbangan yang dianggap peneliti sesuai dengan tujuan penelitian yaitu di Desa Wonokitri, Kecamatan Tosari, kawasan Bromo Tengger Semeru. Penentuan lokasi penelitian tersebut didasarkan atas pertimbangan bahwa: (a) Desa Wonokitri merupakan daerah dengan produksi kentang tertinggi di wilayah Kecamatan Tosari (b) Desa Wonokitri menjadi pemasok kentang skala besar bagi pedagang grosir. Penelitian dilakukan pada bulan Juni hingga September 2014. Penelitian ini berfokus pada pedagang pengumpul lokal yang melakukan distribusi kentang ke pedagang grosir.

Subyek dalam penelitian ini adalah pedagang pengumpul yang tersebar di Desa Wonokitri. Penentuan subyek pedagang pengumpul dilakukan dengan teknik sensus. Penentuan subyek penelitian melihat seluruh elemen-elemen dari informan pedagang pengumpul. Karena populasi pedagang pengumpul relatif sedikit dan variabilitas setiap elemennya yang tinggi (heterogen). Penelitian ini dimaksudkan untuk menjelaskan karakteristik setiap elemen dari pedagang pengumpul. Pedagang pengumpul yang menjadi informan mengetahui sejarah awal hingga sekarang perdagangan di Wonokitri, Kemudian peneliti melakukan pengalian data ke informan pedagang selanjutnya. Keseluruhan pedagang pengumpul berjumlah 14 orang.

Teknik yang diterapkan dalam mengumpulkan data dalam penelitian ini dilakukan dengan:

1. Wawancara secara mendalam (indepth interview) yaitu cara mendapatkan informasi dengan cara memberikan pertanyaan secara langsung kepada pedagang pengumpul yang dapat memberikan informasi lengkap dan mendalam tetang pemasaran kentang. wawancara dilakukan dengan pedagang pengumpul secara sengaja didatangi. Wawancara dilakukan dengan cara diskusi tanpa menganggu aktivitas pedagang pengumpul, yaitu: ikut serta dalam aktivitas pedagang pengumpul. Wawancara dilakukan dengan bentuk diskusi bebas dengan dipandu pertanyaanpertanyaan kunci yang dikembangkan berdasarkan rumusan masalah. Lokasi wawancara dilakukan di rumah, lahan, pasar, saat pedagang pengumpul istirahat, atau sedang bekerja. 
2. Observasi partisipatif dengan mengikuti dan membantu kegiatan perdagangan yang dilakukan pedagang pengumpul. Kegiatan yang diikuti peneliti adalah mulai dari pedagang pengumpul membeli kentang ke petani, berinteraksi dengan karyawan, serta berinteraksi dengan sesama pedagang pengumpul. Kegiatan ini bertujuan untuk mengali informasi bentuk-bentuk strategi yang dilakukan pedagang pengumpul. Hal tersebut dilakukan untuk menjawab pertanyaan penelitian yang belum terjawab melalui wawancara.

3. Dokumentasi, yaitu rekaman feomena aktivitas pemasaran kentang dalam bentuk gambar. Data ini sebagai diambil dalam bentuk visual pedagang pengumpul.

4. Studi Pustaka, hasil penelitian terdahulu dan literatur berupa text book yang berhubungan dengan penelitian ini. Data yang diambil dari instansi pemerintah dalam bentuk laporan tentang kondisi demografi penduduk kawasan Bromo Tengger Semeru. Data dari hasil penelitian terdahulu terdiri dari hasil penelitian strategi pemasaran pada suatu komoditas pertanian. Sedangkan data dari literatur text book terdiri dari ulasan tentang bentuk-bentuk strategi pemasaran pedagang.

Analisis data dalam penelitian berlangsung bersamaan dengan proses pengumpulan data. Analisis ini melalui tiga model, yaitu reduksi data, penyajian data, dan verifikasi. Penelitian ini menggunakan teori Miles dan Huberman dalam buku Usman (2009) yaitu analisis data terdiri dari tiga alur kegiatan yang secara bersamaan yaitu reduksi data, penyajian data, serta penarikan kesimpulan atau verifikasi.

Penelitian ini menggunakan pendekatan emik, yaitu dari pandangan key informan, dan bukan penafsiran makna menurut pandangan peneliti (pendekatan etik). Model interaktif yang menggambarkan keterkaitan ketiga kegiatan reduksi data, penyajian data, dan penarikan kesimpulan atau verifikasi digambarkan seperti berikut:



Gambar 1. Model interaktif dalam analisis data

Pada gambar tersebut tampak adanya ketiga kegiatan yang saling terkait dan merupakan rangkaian yang tidak berdiri sendiri. Penyajian data selain berasal dari hasil reduksi, perlu juga dilihat kembali dalam proses pengumpulan data untuk memastikan bahwa data tersebut sesuai dengan tujuan penelitian. Data yang sudah dikum[pulkan melalui wawancara dianalisis secara deskriptif yaitu dengan mendeskripsikan (memberikan gambaran yang mendalam) dan menginteraksikan fenomena pemasaran di Desa Wonokitri dalam bentuk kalimat, tabel, dan gambara yang memperjelas dalam mendiskripsikan penelitian tentang karakteristik pedagang pengumpul dalam upaya menjaga usaha berdagang kentang di Desa Wonokitri. Proses tersebut akan didaptkan kesimpulan berupa strategi-strategi yang muncul dari setiap pedagang pengumpul.

\section{Hasil dan Pembahasan}

\subsection{Karakteristik Pedagang Pengumpul Kentang}

Dapat disimpulkan bahwa karakteristik pedagang pengumpul lebih dominan pada skala distribusi sedang dengan rata-rata jumlah pengiriman minimal 3 pick up/minggu. Jumlah pengiriman kentang tersebut disesuaikan dengan modal yang dimiliki pedagang pengumpul dan permintaan pasar. Sedangkan pengalaman berdagang mayoritas pedagang pengumpul pada kategori berpengalaman dengan dengan rata-rata usia > 20 tahun menjadi pedagang pengumpul dan ketersediaan informasi yang luas. 


\subsection{Faktor-Faktor Yang Mempengaruhi Karakteristik Pedagang Pengumpul}

Faktor-faktor yang mempengaruhi yaitu sebagai berikut:

1. Jangkauan pasar paling dominan pada kategori luas dengan indikator pengiriman kentang ke pasar skala nasional, memiliki sistem informasi yang luas tentang peluang pemasaran, dan memiliki peluang pengiriman ke luar pulau.

2. Pengambilan risiko lebih dominan pada kategori sedang dengan indikator yang berisiko mengalami kerugian sedang ketika harga kentang fluktuatif, berisiko sedang terhadap pembatalan pengiriman kentang ketika terjadi perubahan cuaca dan iklim, serta memiliki risiko sedang ketika proses pengiriman kentang.

3. Jaringan sosial yang dijalin pedagang pengumpul lebih dominan pada kategori kuat dengan indikator melakukan komunikasi secara efisien dengan menjalin hubungan secara berkelanjutan, melakukan komunikasi sosial dengan pedagang grosir, petani, dan sesama pedagang pengumpul secara kuat.
4. Kontrak bisnis, mayoritas pedagang pengumpul menganggap bahwa kontrak bisnis dominan pada kateogri eifisen dengan melakukan pinjaman modal ke petani secara penuh, dan melakukan pembelian secara tebas dengan sistem pembelian $>50 \%$.

\subsection{Pola Saluran Pemasaran Pedagang Pengumpul}

Menurut Swastha (1981), Saluran pemasaran mempunyai pungsi penyedia fisik menyangkut perpindahan barang-barang secara fisik dari produsen sampai konsumen. Ada empat macam fungsi yang termasuk dalam penyediaan fisik. Fungsi tersebut adalah: pengumpulan, penyimpanan, pemilihan dan pengangkutan. sedangkan fungsi pertukaran, dan fungsi penunjang dalam pelaksanaannya perlu memperoleh dukungan berupa penyediaan informasi yang diperlukan. Dengan sendirinya, informasi yang dibutuhkan akan berbeda-beda sesuai dengan jenis barang dan macam serta sifat saluran distribusinya. Hasil penelitian di Desa Wonokitri, terdapat 4 macam pola saluran pemasaran yang dikelola secara bersama-sama berdasarkan faktor-faktor yang mempegaruhi yaitu sebagai berikut:

1. Pola Saluran Berdasarkan Jangkauan Pasar

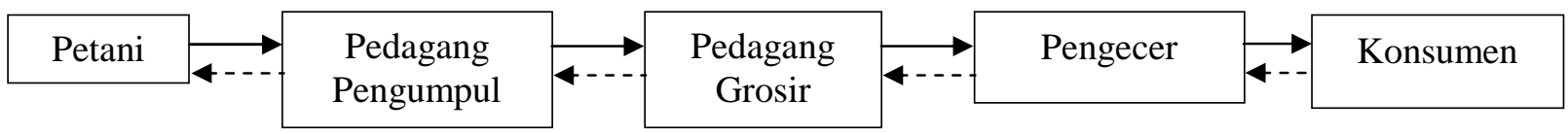

Keterangan:

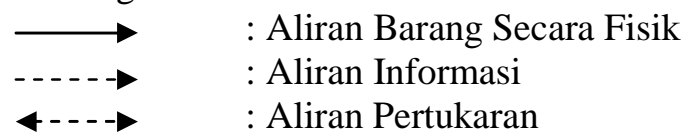

Gambar 2. Tipe saluran 1

Berdasarkan pola saluran pemasaran yang dilihat dari pengalaman berdagang dapat memberikan gambaran bahwa pola saluran pemasaran tersebut sangat sering diberlakukan pada pemasaran kentang di Desa Wonokitri. Aliran barang dari petani yang disalurkan ke pedagang pengumpul melalui proses tawarmenasawr merupakan inti dari pemasaran dalam penelitian ini. Sehingga dapat disimpulkan bahwa untuk menjagkau pasar yang luas, pedagang pengumpul harus menerapkan pola saluran pemasaran ini dengan menerapkan strategi yaitu: membangun kepercayaan denga petani dan membuat jaringan yang luas dengan pedagang grosir untuk memperbanyak saluran pemasaran kentang.

Berdasarkan pengambilan risiko, pola pemasaran tersebut lebih menekankan pada aspek hubungan antara pedagang pengumpul dengan petani. Pengambilan risiko ini berhubungan dengan pengawasan kualitas kentang di petani. Pedagang pengumpul harus selalu memantau dan melakukan pengecekan kepada kentang yang akan dibeli dari petani. Pola saluran ini memberikan penjelasan bahwa pedagang pengumpul melakukan pertukaran fisik berupa produk kentang dengan meberikan informasi harga dan permintaan kepada petani. Sehingga 
dapat disimpulkan bahwa untuk mengurangi risiko, pedagang pengumpul harus melakukan pemantauan kualitas kepada petani agar dapat memuaskan pedagang grosir sebagai konsumen.

\section{Pola Saluran Berdasarkan Pengambilan Risiko}



Keterangan:

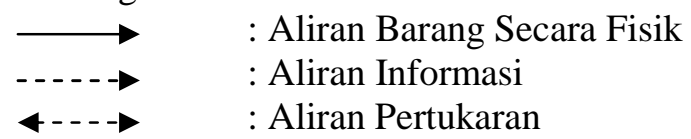

Gambar 3. Tipe saluran 2

3. Pola Saluran Pemasaran Berdasarkan Jaringan Sosial

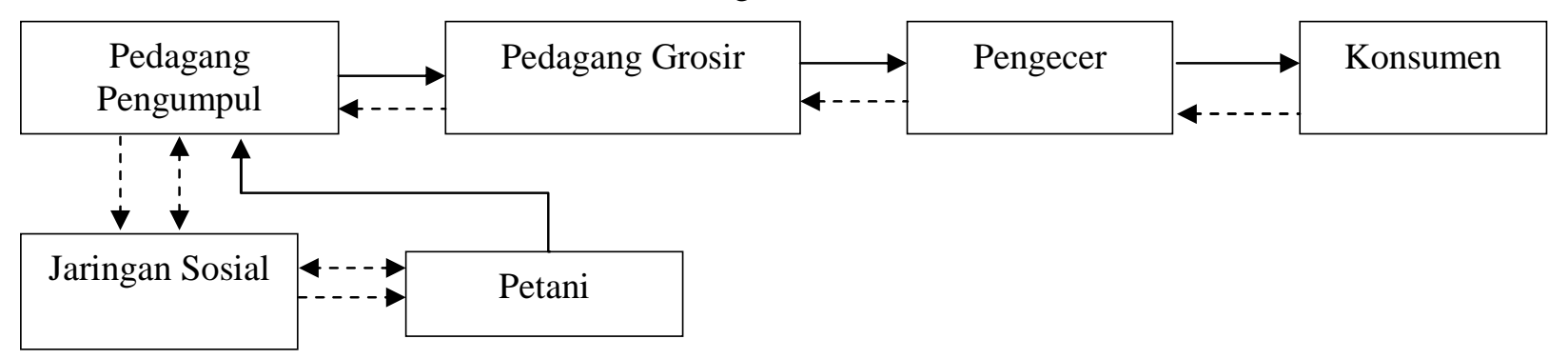

Keterangan:

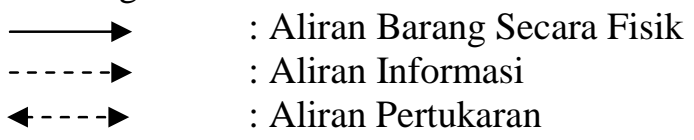

Gambar 4. Tipe saluran 3

Sistem pada pola saluran berdasarkan jaringan sosial ini menyangkut pengaruh interaksi pedagang pengumpul dengan petani. Pedagang pengumpul memperkuat jaringan sosial dengan melakukan komunikasi sosial dengan tujuan untuk memberikan kemudahan dalam membentuk jaringan sosial secara berkelanjutan. Pola saluran ini dilakukan pedagang pengumpul untuk mempermudah dalam pembelian kentang milik petani melalui pertukaran informasi yang menyangkut kepentingan petani seperti: informasi bibit unggul, informasi harga, informasi pemasaran dan hal-hal lain yang membuat petani merasa membutuhkan pedagang pengumpul tersbut. Sehingga berdasarkan pola saluran tersebut dapat disimpulkan bahwa dalam membentuk jaringan sosial yang kuat, pedagang pengumpul harus melakukan komunikasi dan sharing ke petani untuk membangun keterikatan.

Pola saluran berdasarkan kontrak bisnis tersebut dilakukan melalui pinjaman modal atau sistem pembelian. Pedagang pengumpul melakukan pengambilan kentang ke petani berdasarkan sisitem kontrak bisnis yang sudah disepakati. Kondisi ini mempermudah pedagang pengumpul karena sudah memiliki persediaan kentang untuk di pasarkan ke pedagang grosir. Melihat kemudahan ini, pedagang pengumpul memiliki pola saluran ini yaitu dengan melakukan penjemputan kentang ke petani. Pola saluran ini lebih efisien karena pedagang pengumpul tidak kesulitan mencari kentang milik petani. Ketika terjadi permintaan dari pedagang grosir, maka pedagang pengumpul langsung mengambil persediaan kentang di petani yang sudah melakukan kontrak bisnis tersebut. Sehingga dapat disimpulakn bahwa kontrak bisnis melalui pinjaman modal dan sistem pembelian dapat membentuk pola saluran pemasaran yaitu pedagang pengunpul mengambil langsung ke petani. 
4. Pola Saluran Pemasaran Berdasarkan Kontrak Bisnis

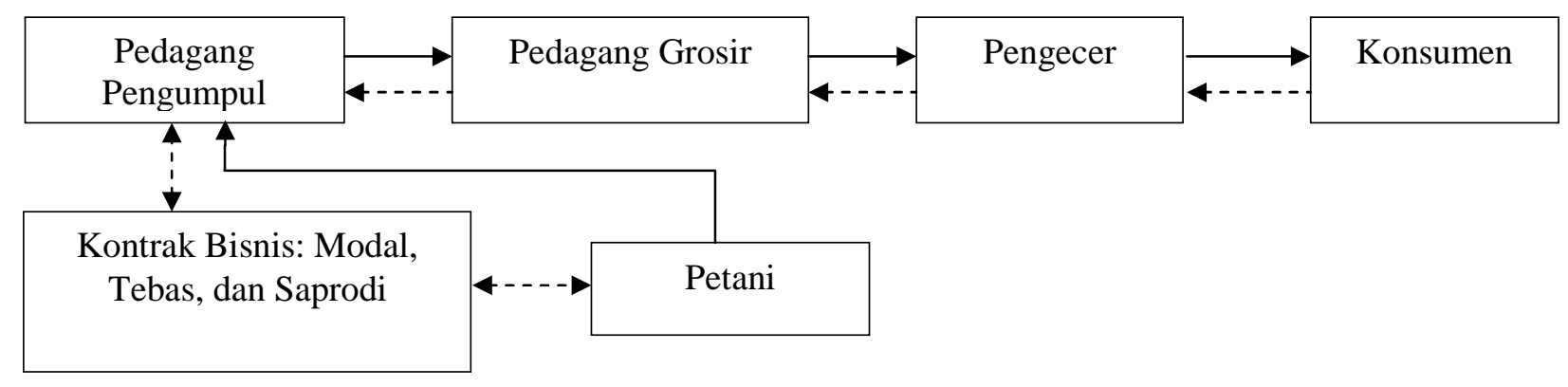

Keterangan:



Gambar 5. Tipe saluran 4

\subsection{Strategi Pedagang Pengumpul dalam Upaya Menjaga Usaha Berdagang}

Berdasarkan hubungan karakteristik pedagang pengumpul, yaitu pengalaman berdagang dan skala distribusi dengan faktorfaktor yang mempengaruhi yaitu indikatornya: jangkauan pasar, pengambilan risiko, jaringan sosial, dan kontrak bisnis dapat memberikan bambaran secara jelas perilaku pedagang pengumpul. Berdasarkan perilaku pedagang pengumpul tersebut, hasil akhirnya adalah untuk mengetahui strategi pedagang pengumpul dalam menjaga keberlangsungan usaha perdagangan kentang.

1. Strategi pedagang berdasarkan pengalaman berdagang untuk menjaga keberlangsungan usaha

Tabel 1. Strategi pedagang pengumpul berdasarkan pengalaman berdagang untuk menjaga keberlangsungan usaha

\begin{tabular}{lcccc}
\hline \multicolumn{1}{c}{ Jenis Pengalaman } & \multicolumn{4}{c}{ Faktor-faktor yang Mempengaruhi } \\
\cline { 2 - 5 } & $\begin{array}{c}\text { Jangkauan } \\
\text { Berdagang }\end{array}$ & $\begin{array}{c}\text { Pengambilan } \\
\text { Risiko }\end{array}$ & $\begin{array}{c}\text { Jaringan } \\
\text { Sosial }\end{array}$ & Kontrak Bisnis \\
\hline Berpengalaman & Luas & Sedang & Kuat & Efisien \\
Cukup Berpengalaman & Luas & Tinggi & Kuat & Efisien \\
Kurang Berpengalaman & Luas & Tinggi & Kuat & Efisien \\
\hline
\end{tabular}

Berdasarkan Tabel 1., dapat dijelaskan bahwa strategi pedagang dalam menjaga usaha pemasaran yaitu sebagai berikut:

\section{a. Berpengalaman}

Pada kategori berpengalaman, pedagang pengumpul lebih melakukan jangkauan pasar secara luas. Jangkauan pasar luas ini dilakukan untuk tetap menjaga suplai kentang ke berbagai pasar. Kemudian pengambilan risiko lebih memilih pada kategori sedang. Pengambilan risiko sedang mendominasi, karena pedagang pengumpul bisa menganalisa kondisi pasar berdasarkan pengalaman berdagang yang mayoritas $>20$ tahun terjun sebagai pedagang kentang. Pedagang pengumpul tidak terlalu terburu-buru dalam mengambil keputusan karena sudah memahami betul kondisi yang akan terjadi berdasarkan pengalamannya. Pedagang pengumpul lebih menjalin jaringan sosial ke petani dengan kuat untuk dapat menguasai kentang milik petani yang ada di Desa Wonokitri. Jaringan sosial yang dipilih lebih kepada jaringan sosial kuat dengan mempertimbangkan komunikasi secara intensif dan berkelanjutan. Sistem jaringan sosial ini dapat berbentuk kontrak bisnis berupa pemberian modal, saprodi dan sistem pembelian tebas. Kontrak bisnis melalui pembelian secara tebas cukup sesuai dengan kondisi di Desa Wonokitri. Sehingga pedagang pengumpul menganggap bahwa kontak bisnis efisien bila diterapkan di wilayah Wonokitri. 


\section{b. Cukup berpengalaman}

Kategori cukup berpengalaman melakukan jangkauan pasar lebih dominan pada pasar secara luas. Jangkauan luas ini disebabkan karena posisi pasar yang jauh mempunyai jumlah permintaan yang lebih tinggi dibandingkan permintaan pada pasar skala lokal. Jangkauan pasar luas megakibatkan pedagang dengan pengalaman 1020 tahun lebih memilih pengambilan risiko tinggi. Risiko tinggi ini lebih dipilih karena dianggap sesuai untuk meningkatkan usaha pemasaran bagi pedagang pengumpul. Pedagang pengumpul berpendapat bahwa semakin tinggi tingkat risiko, maka semakin tinggi pendapatan yang diperoleh. Hal tersebut sesuai dengan yang dikemukakan Mar'at dalam Soekartawi (1993), bahwa sikap seseorang merupakan hasil dari proses belajar, proses pengalaman dari frame of reference seseorang. Walaupun pedagang pengumpul seringkali dihadapkan kepada situasi ketidakpastian harga dan permintaan, mereka selalu mengejar usaha-usaha untuk meningkatkan jumlah pendapatan melalui perbaikan-perbaikan strategi dan peluang-pluang lain yang dapat dimanfaatkan. Peluang dan startegi tersebut dapat berupa mengganti komoditas pemasaran lain seperti kubis, bawang daun. Sekalipun disisi lain mereka menyadari bahwa akan menghadapi risiko yang lebih besar apabila menerapkan startegi-strategi lain.

Pedagang pengumpul dalam mengurangi terjadinya risiko, maka harus membentuk suatu jaringan sosial yang kuat. Jaringan sosial yang kuat merupakan suatu strategi lain yang dipilih pedagang pengumpul. Jaringan sosial di pihak petani dan pedagang diawali dari kegiatankegiatan sosial yang mendukung aktivitas pedagang sehingga terjadi efisiensi biaya transaksi. Pada awalnya dimulai ketika ada kegiatan sosial, kemudian terjadi hubungan sosial antara pedagang dan petani secara berlanjut. Hubungan sosial tersebut mengakibatkan terjadinya kontrak bisnis melalui pembiayaan usahatani kentang. Biaya-biaya yang harus di tanggung petani dan pedagang dalam menjalankan aktivitasnya pada pemasaran kentang diantaranya, yaitu biaya panen merupakan biaya yang di keluarkan saat terjadi proses aktivitas di lahan produksi yang digunakan secara operasional pemanenan mulai dari biaya tenaga kerja sampai pada biaya pengangkutan.

\section{c. Kurang berpengalaman}

Kategori kurang berpengalaman dilakukan oleh pedagang pengumpul dengan $<10$ tahun melakukan pemasaran kentang. Pedagang pengumpul dengan pengalaman yang relatif paling sedikit tidak menutup kemungkinan bisa bersaing dengan pedagang pengumpul lain. Hal tersebut dibuktikan dengan adanya jangkauan pasar secara luas. Jangkauan pasar luas tersebut merupakan tujuan pedagang pengumpul untuk bisa mengimbangi pedagang pengumpul dengan pengalaman berdagang berbeda-beda. Pedagang pengumpul harus menyesuaikan diri dengan pedagang lain dengan berani mengambil risiko tinggi agar bisa bersaing lebih meningkatkan skala usaha pemasaran kentang. Peningkatan skala usaha tersebut harus diimbangi melalui pengumpulan informasi secara luas dengan membentuk jaringan sosial yang kuat dengan petani dan pedagang grosir. Jaringan sosial yang kuat akan menghasilkan kontrak bisnis yang sesuai dengan kondisi di Desa Wonokitri. Kontrak bisnis dapat melalui sistem pembelian tebas sesuai kesepakatan antara pedagang pengumpul dan petani.

2. Strategi Pedagang Pengumpul dalam Menjaga Usaha Berdagang Kentang Berdasarkan Skala Distribusi

Tabel 2. Strategi pedagang pengumpul berdasarkan skala distribusi untuk menjaga keberlangsungan usaha

\begin{tabular}{lcccc}
\hline \multicolumn{1}{c}{ Skala } & \multicolumn{4}{c}{ Faktor-faktor yang Mempengaruhi } \\
\cline { 2 - 5 } Distribusi & Jangkauan Pasar & Pengambilan Risiko & Jaringan Sosial & Kontrak Bisnis \\
\hline Besar & Luas & Tinggi & Kuat & Efisien \\
Sedang & Luas & Sedang & Kuat & Efisien \\
Kecil & Luas & Rendah & Lemah & Cukup Efisien \\
\hline
\end{tabular}

Berdasarkan Tabel 2., dapat dijelaskan bahwa strategi pedagang berdasarkan skala distribusi yang dihubungkan dengan faktor-faktor yang mempengaruhinya yaitu sebagai berikut:

\section{a. Skala distribusi besar}

Skala distribusi besar membentuk suatu strategi yang mempengaruhi jagkauan pasar. 
Skala distribusi besar mampu melakukan pengirman minimal 1 kali dalam sehari. Berdasarkan jumlah pengiriman tersebut, mengakibatkan pedagang pengumpul harus bisa menjangakau pasar yang luas yaitu meliputi pasar di berbagi daerah di Jawa Timur. Pasar yang menjadi fokus utama adalah meliputi Pasar di Malang raya dan Surabaya. Pedagang pengumpul bisa memenuhi pasokan kentang dari daerah Ngantang dan daerah Pujon melalui pengiriman yang kontinu. Jarak pasar sasaran yang relatif jauh mengakibatkan tingginya risiko kecelakaan. Pedagang pengumpul harus berani untuk menanggung risiko tersebut karena memang konsekuensi sebagai pedagang untuk bisa menjalankan usaha pemasaran kentang.

Akibat pengiriman yang relatif besar ke berbagai pasar dan pedagang grosir, maka pedagang pengumpul harus menjalin jaringan sosial yang kuat untuk membangun kepercayaan secara keberlanjutan. Jaringan sosial tidak hanya ditunjukkan melalui komunikasi transaksional, tetapi dengan menjaga kualitas kentang. Pedagang grosir yang merasa puas dengan kualitas kentang sesuai pesanan, maka akan menunjukkan perilaku kepuasan pelanggan dengan melakukan pemesanan secara kontinu. Sedangkan kontrak bisnis dengan petani, pedagang pengumpul harus memahami kondisi yang dibutuhkan petani. Petani lebih memilih untuk diberi pinjaman modal usahatani. Pedagang pengumpul juga harus menyesuaikan kebutuhan modal bagi petani dengan melihat luas lahan dan keseriusan petani dalam berusahatani kentang. Secara keseluruhan kontrak bisnis tersebut efisien karena pedagang pengumpul skala distribusi besar menggunakan sistem tersebut.

\section{b. Skala distribusi sedang}

Skala distribusi sedang melakukan jangkauan pasar secara luas. Jangkauan pasar luas ini memang digunakan oleh sebagian besar pedagang pengumpul. Setiap pedagang pengumpul memiliki langganan masing-masing. Tiap-tiap pedagang pengumpul yang ada di Desa Wonokitri tidak saling melakukan tumpang tindih apabila melakukan pengiriman ke pedagang grosir. Terjadinya perbedaan langaanan tiap pedagang pengumpul tersebut mengakibatkan pengambilan risiko yang diambil pada kategori sedang. Kategori pengambilan risiko sedang lebih melakukan peninjauan secara detail, seperti kepastian jumlah permintaan dari pedagang grosir, kepastian harga, kepastian kualitas kentang yang diminta pedagang grosir. Melihat peninjuan tersebut, pedagang pengumpul harus menjalin jaringan sosial yang kuat untuk memastikan bahwa informasi-informasi yang muncul dapat dipertanggungjawabkan. Jaringan sosial yang kuat dan pengambilan risiko sedang tersebut diimplementasikan pada kontrak bisnis berupa sistem pembelian tebas dan sistem pinjaman bibit atau saprodi. Kontrak bisnis merupakan penerapan yang cukup efisien, karena melihat jumlah pengiriman yang besar yaitu minimal 1 pick up dalam 3 hari sekali pedagang harus memutar modal. Sehingga dengan keterbatasan modal, pedagang pengumpul lebih menerapkan pinjaman bibit kepada petani.

\section{c. Skala distribusi kecil}

Skala distribusi kecil ini lebih mengandalkan sedikit pedagang grosir yang berperan didalamnya. Pedagang grosir melakukan pengambilan kentang ke pedagang pengumpul. Pedagang grosir mayoritas merupakan pedagang dengan skala distribusi secara luas. Pedagang pengumpul bertugas mengumpulkan kentang milik petani tanpa harus melakukan pengangkutan ke berbagai pasar. Hal tersebut mengakibatkan pengambilan risiko termasuk rendah. Karena jumlah kentang yang dikumpulkan dari petani hanya sebatas kemampuan pedagang pengumpul saja. Tetapi untuk mengumpulkan kentang dalam jumlah besar, maka pedagang grosir mengumpulkan banyak pedagang pengumpul skala distribusi kecil.

Berdasarkan peran pedagang pengumpul yang hanya mengumpulkan kentang milik petani, maka jaringan sosial yang terjalin termasuk kategori lemah. Karena pedagang pengumpul hanya mengandalkan pedagang grosir yang datang, bukan pedagang pengumpul melakukan komunikasi sendiri dengan pelaku pemasaran. Pedagang pengumpul kurang memahami kondisi pasar karena kurangnya informasi yang didapatkan pedagang pengumpul. Selanjutnya untuk kontrak bisnis, pedagang pengumpul kurang memiliki modal dan sapordi untuk dipinjamkan petani. Sehingga kontrak bisnis kurang efisien apabila diterapkan pada pedangan pengumpul skala distribusi kecil.

\section{Kesimpulan}

Karakteristik pedagang pengumpul lebih dominan pada skala distribusi sedang dengan rata-rata jumlah pengiriman minimal 3 pick 
up/minggu. Jumlah pengiriman kentang tersebut disesuaikan dengan modal yang dimiliki pedagang pengumpul dan permintaan pasar. Sedangkan pengalaman berdagang mayoritas pedagang pengumpul pada kategori berpengalaman dengan dengan rata-rata usia $>20$ tahun menjadi pedagang pengumpul dan ketersediaan informasi yang luas.

$\begin{array}{crr}\text { Faktor-faktor yang } & \text { mempengaruhi } \\ \text { pedagang perdasarkan }\end{array}$ karakteristiknya yaitu sebagai berikut:

1. Jangkauan pasar paling dominan pada kategori luas dengan indikator pengiriman kentang ke pasar skala nasional, memiliki sistem informasi yang luas tentang peluang pemasaran, dan memiliki peluang pengiriman ke luar pulau.

2. Pengambilan risiko lebih dominan pada kategori sedang dengan indikator yang berisiko mengalami kerugian sedang ketika harga kentang fluktuatif, berisiko sedang terhadap pembatalan pengiriman kentang ketika terjadi perubahan cuaca dan iklim, serta memiliki risiko sedang ketika proses pengiriman kentang.

3. Jaringan sosial yang dijalin pedagang pengumpul lebih dominan pada kategori kuat dengan indikator melakukan komunikasi secara efisien dengan menjalin hubungan secara berkelanjutan, melakukan komunikasi sosial dengan pedagang grosir, petani, dan sesama pedagang pengumpul secara kuat.

4. Kontrak bisnis, mayoritas pedagang pengumpul menganggap bahwa kontrak bisnis dominan pada kateogri eifisen dengan melakukan pinjaman modal ke petani secara penuh, dan melakukan pembelian secara tebas dengan sistem pembelian $>50 \%$.

Pola saluran pemasaran terdapat 4 variasi aliran kentang dari petani menuju konsumen akhir. Variasi aliran kentang tersebut dibedakan atas model pengambilan kentang, yaitu 1) pedagang pengumpul melakukan pengambilan kentang langsung ke petani, 2) petani melakukan pengiriman kentang ke pedagang pengumpul, 3) petani yang juga sebagai pedagang pengumpul mengirim langsung ke pedagang grosir, 4) pedagang grosir mengambil langsung kentang ke petani dan pedagang pengumpul.
Berdasarkan karakteristik pedagang
pengumpul, maka didapatkan $\begin{array}{r}\text { strategi } \\ \text { berdasarkan pengalaman berdagang yang } \\ \text { dilakukan pedagang, yaitu: }\end{array}$

1. Pedagang pengumpul yang berpengalaman lebih menanggung risiko sedang dengan melakukan strategi pembelian kentang dalam jumlah besar dengan menganalisis situasi pasar terlebih dahulu. Dengan jumlah kentang yang dibeli dalam skala besar, maka jaringan sosial yang dipakai adalah komunikasi langsung secara kuat dengan melakukan negosiasi kepada petani. Sehingga dengan komunikasi langsung pedagang pengumpul lebih melakukan kontrak bisnis harga dengan mengikat petani dalam persetujuan harga diawal untuk memetakan besarnya kentang yang dapat dikuasai pedagang pengumpul.

2. Pedagang pengumpul cukup berpengalaman dengan jangkauannya adalah pasar skala nasional pedagang melakukan strategi bisa menguasai sebagian besar petani di Desa Wonokitri. Melihat wilayah lahan kentang di Wonokitri cukup luas, maka pengambilan risiko sedang. Kemudian jaringan sosial lebih memilih menjalin hubungan sosial secara kuat. Hal tersebut dialakukan pedagang pengumpul untuk menguasai kentang milik tetangga disekitar wilayah yang mudah dijangkau. Sehingga kontrak bisnis eifisin yang dipakai pedagang adalah kontrak harga dan modal yang menurut pedagang pengumpul lebih menguntungkan karena dianggap paling menguntungkan dai segi finansial.

3. Pedagang kurang berpengalaman harus bisa menjagakau pasar luas agar dapat menguasai pasar nasional dan bisa bersaing dengan pedagang pengumpul lain. Melihat persaingan yang cukup tinggi, pedagang pengumpul harus menggunakan strategi pengambilan risiko rendah untuk dapat memaksimalkan persaingan. Melihat risiko yang rendah, maka pedagang pengumpul hanya bisa mengikat pedagang melaui jaringan sosial yang lemah seperti membeli kentang milik tetangga saja. Hal ini dilakukan untuk meminimalisir risiko yang disesuaikan dengan modal petani. Kemudian untuk menyesuaikan hal tersebut, maka pedagang pengumpul harus 
melakukan cukup efisien dalam melakukan kontrak bisnis pemberian modal ke petani. Pemberian modal ini cukup efektif karena pedagang pengumpul dapat bisa berperan aktif dalam usahatani dengan petani yang menjadi kontrak bisnisnya.

Strategi yang dilakukan pedagang pengumpul berdasarkan skala distribusi yaitu sebagai berikut:

1. Skala distribusi besar jangkauan pasarnya luas dengan menjangkauan pasar skala nasional dengan pengambilan risiko sedang. Pengambilan risiko sedang disesuaikan dengan jumlah permintaan yang ada di pasar sasaran. Pedagang pengumpul melihat situasi pasar terlebih dahulu untuk meminimalisir terjadinya risiko. Kemudian jaringan sosial yang dijalin adalah menggunakan jaringan yang kuat melalui pendekatan komunikasi dengan tetangga, saudara dan petani luar untuk membentuk jaringan sosial yang solid. Jaringan sosial yang kuat, akan membentuk kontrak bisnis yang efisien apabila diterapkan kepada petani dan pedagang pengumpul.

2. Skala distribusi sedang lebih menjagkuan pasar yang luas. jangkauan pasar luas merupakan indikasi terjadinya pengiriman kentang ke pasar skala nasional. Pedagang pengumpul lebih efektif melakukan pengambilan risiko sedang. Selanjutnya jaringan sosial secara lemah lebih dipilih pedagang pengumpul karena skala pengiriman kecil. Pedagang pengumpul tidak membutuhkan interaksi secara intensif ke banyak petani dan pedagang grosir untuk melakukan pengiriman kentang. sehingga kontrak bisnis oleh pedagang skala distribusi kecil cukup efisien apabila diterapkan.

3. Skala distribusi kecil jangkauan pasar luas kepada pasar nasional dengan pengambilan risiko paling efektif rendah. Kemudian jaringan sosial lemah dengan mengandalkan komunikasi langsung lebih dpilih pedagang pengumpul. Sehingga dapat dikatakan bahwa kontrak bisnsi yang dilakukan cukup efisien di pedagang skala distribusi kecil.

\section{Daftar Pustaka}

[1]. Barry, P.J. 1984. Risk Management in Agriculture. The lowa State University Press. Ames. Lowa.

[2]. Damsar. 1997. Sosiologi Ekonomi. PT RajaGrafindo Persada: Jakarta.

[3]. Dirjen Hortikultura. 2012. Produksi Kentang di Indonesia. Jakarta.

[4]. Dirjen Pemberdayaan Masyarakat dan Desa. 2014. (http://www.prodeskel.pmd.kemendagri.go .id/mpublik/).

[5]. Debertin, J.L. 1979. Bernoullian Decision Theory Outline and Problems. dalam Roumasset, J.A,J.M. Boussard and I. Singh (Ed.) p. 23-28. Risk, Uncertainly and Agricultural Development. Agricultural Development Council. New York.

[6]. Eni 2010. Analisis Rantai dan Efisiensi Pemasaran Cabai Rawit Merah Kecamatan Ngemplak, Kab. Sleman, Sosial Ekonomi Pertanian Fakultas Pertanian Universitas Brawijaya: Perpustakaan Pusat UB.

[7]. Gitosudarmo, Indriyo \& Agus Mulyono, 1999, Prinsip Dasar Manajemen, Yogyakarta: BPFE.

[8]. Granovetter, Mark in Neil J. Smelser and Richard Swedberg, (eds). 2005. Handbook of Economic Sociology. Russel Sage Foundation: Princeton University Press.

[9]. Hanafiah. A.M. dan Saefuddin. A. M., 1983. Tataniaga Hasil Perikanan. UI Press, Jakarta.

[10]. Just, R.E., dan R.D. Pope. 1979. Production Function Estimation and Related Risk Considerations. American Journal of Agricultural Economics. 61 (2). hlm. 276-284.

[11]. Kartasapoetra G. 1985. Manajemen Pertanian Agribisnis. PT. Bina Aksara. Jakarta.

[12]. Mar'at. 1984. Sikap Manusia, Perubahan Serta Pengukurannya. Ghalia Indonesia. Jakarta.

[13]. Miles dan huberman dalam buku usman. 2009. Metode Penelitian Sosial. Bumi Pusaka. Jakarta. 
[14]. Mismayati. 2003. Strategi Pemasaran Apel Manalagi di CV. Prestige Fruits Apples Kec. Poncokusumo, Kab. Malang, Skripsi Jurusan Sosial Ekonomi Agribisnis Fakultas Pertanian Universitas Brawijaya, Malang.

[15]. Padmanabhan, K.P. 1988. Rural Credit, Lessons for Rural Bankers and Policy Makers. Intermediate Technology Publications Ltd. London.

[16]. Powell dan Smith-Doerr, dalam Damsar. 1997. Sosiologi Ekonomi. PT RajaGrafindo Persada. Jakarta.

[17]. Sa'id, E. Gumbira dan A Harizt Intan. 2001. Manajemen Agribisnis. PT. Ghalia Indonesia. MMA-IPB.

[18]. Soekartawi, et. al. 1993. Risiko dan Ketidakpastian dalam Agribisnis. PT. RajaGrafindo Persada. Jakarta.
[19]. Stanton, William J. dan Y. Lamarto. 1993. Prinsip Pemasaran Jilid 1. Erlangga. Jakarta.

[20]. Sumiwaharja Surachman, et. al. 1988. Initisari Manajemen Pemasaran. CV. Remadja Karya. Bandung.

[21]. Swastha. 1981. Saluran Pemasaran. Bagian Penerbit Fakultas Ekonomi UGM. Yogyakarta.

[22]. Utomo, Medea Ramadhani. 2012. Adaptabilitas Pasar Sayur Kecil Terhadap Pertumbuhan Pasar Sayur Skala Besar di Malang, Jawa Timur. Skripsi Jurusan Agribisnis Fakultas Pertanian Universitas Brawijaya: Perpustakaan pusat UB.

[23]. Yulaicha. 2008. Pola Hubungan Pada Lembaga Pemasaran Apel Poncokusumo, Kab. Malang. Skripsi Jurusan Sosial Ekonomi Pertanian Fakultas Pertanian Universitas Brawijaya: Perpustakaan Pusat UB. 